\title{
KRISIS EKOLOGI DALAM CERPEN IKAN KARYA DANANG FEBRIANSYAH
}

\section{ECOLOGICAL CRISIS IN THE SHORT STORY OF IKAN BY DANANG FEBRIANSYAH}

\author{
Randa Anggarista \\ Dosen Pendidikan Bahasa dan Sastra Indonesia, Fakultas Keguruan dan Ilmu \\ Pendidikan, Universitas Qamarul Huda Badaruddin. \\ Randa.anggarista1992@yahoo.com
}

\begin{abstract}
ABSTRAK
Penelitian ini merupakan penelitian kualitatif dengan menggunakan perspektif ekokritik. Data dalam penelitian ini berupa teks yang mengacu pada rumusan masalah tentang bentuk krisis ekologi dalam cerpen Ikan, sedangkan sumber data yang digunakan yaitu cerpen Ikan karya Danang Febriansyah. Instrumen dalam penelitian ini yaitu penulis yang berorientasi pada penelitian teks cerpen Ikan karya Danang Febriasnsyah. Uji validitas dalam penelitian ini menggunakan validitas semantis yang berorientasi pada kedalaman proses interpretasi. Teknik pengumpulan data dalam penelitian ini dilakukan dengan teknik baca dan catat. Adapun teknik analisis data yang digunakan yaitu klasifikasi, interpretasi, dan penarikan simpulan. Berdasarkan hasil penelitian, dalam cerpen Ikan karya Danang Febriansyah, ditemukan adanya representasi tentang krisis ekologi dalam bentuk kerusakan ekosistem biotis dan makhluk hidup dalam ekosistem mengalami kepunahan.
\end{abstract}

Kata kunci: krisis ekologi dan ekokritik.

\begin{abstract}
This research is a qualitative study using an ecocriticism perspective. The data in this study are form of text that refers to the formulation of problem about the form of ecological crisis in the short story of Ikan, while the data source used is the short story of Ikan by Danang Febriansyah. The instrument in this research is writer who oriented to research the short story of Ikan by Danang Febriasnsyah. The validity test in this study uses semantic validity which is oriented to depth of interpretation process. Data collection techniques in this study were carried out by reading and note-taking techniques. The data analysis techniques used are classification, interpretation, and drawing conclusions. Based on the research results, in the short story of Ikan by Danang Febriansyah, it was found that there was a representation of the ecological crisis in form of damage to the biotic ecosystem and the living things in ecosystem experiencing extinction.
\end{abstract}

Keywords: ecological crisis, ecocriticism 


\section{PENDAHULUAN}

Karya sastra merupakan salah satu bagian terpenting dalam membangun paradigma hidup manusia. Setiap teks sastra yang lahir dari tangan seorang penulis (sastrawan), tentu saja tidak lahir dengan kekosongan perspektif. Hal itu berarti bahwa teks sastra memberikan representasi tentang kondisi lingkungan tempat sastra itu dilahirkan. Endraswara (2016:1) mengatakan bahwa perubahan iklim, budaya, masa kepunahan lingkungan, dan degradasi moral sering menjadi bagian penting dalam membangun teks sastra. Hal itu sekaligus menjadi indikasi bahwa teks sastra tidak pernah lepas dari kondisi lingkungan.

Seiring dengan berkembangnya zaman, terutama dengan munculnya berbagai bentuk penggunaan alat teknologi modern membuat kerusakan ekosistem alam menjadi salah satu fenomena sekaligus bagian yang tidak terpisahkan dari perilaku manusia. Pandangan manusia yang antroposentris, menyebabkan aktivitas perburuan margasatwa dan eksploitasi alam dalam bentuk illegal logging menjadi problematika dan masalah besar bagi dunia modern. Penebangan pohon yang tidak terkendali, penambangan liar, limbah rumah tangga yang meningkat dengan begitu signifikan, serta tercemarnya ekosistem sungai dan laut, menjadi perhatian serius bagi kehidupan manusia. Alam (lingkungan hidup) dengan berbagai jenis kekayaannya menjadi salah satu faktor penunjang keberlangsungan hidup (eksistensi) manusia di tengah sistem ekologis.

Oleh karena itu, untuk menanggulangi berbagai bentuk sikap amoral dan degradasi ekologi tersebut, pemerintah, masyarakat sipil, bahkan para sastrawan ikut andil menyuarakan perlawanan untuk menanggulangi kerusakan ekosistem alam. Pemerintah membuat berbagai bentuk peraturan yang memberikan dukungan penuh untuk menghalangi kerusakan ekosistem alam. Adapun para sastrawan seringkali menggunakan diksi lingkungan hidup untuk menjadi bagian penting yang tidak bisa terpisahkan dengan teks sastra yang dihasilkannya. Melalui para sastrawan, lahir berbagai jenis karya sastra yang bernuansa ekologis dengan tujuan untuk memberikan pemahaman kepada manusia tentang posisinya di tengah ekosistem.

Beberapa teks sastra yang menggunakan diksi alam dalam alur ceritanya yaitu pertama, novel Ronggeng Dukuh Paruk karya Ahmad Tohari (2011). Melalui teks sastra tersebut, Tohari memberikan representasi tentang kondisi alam Pulau Jawa yang tandus namun perilaku masyarakatnya tetap menjunjung tinggi nilai-nilai kearifan lokal. Kedua, cerpen Pohon Jejawi karya Budi Darma yang termuat dalam ontologi cerpen Dodolitdodolitdodolibret (2014). Melalui teks cerpen tersebut, Darma memberikan gambaran tentang perlawanan masyarakat dan mitos pohon jejawi terhadap regulasi kapitalisme yang diterapkan oleh pemerintah kolonial. Ketiga, novel Sarongge karya Tosca Santoso (2012) yang memberikan gambaran secara eksploratif tentang perlawanan tokoh Husin dan Karen untuk menanggulangi berbagai usaha pengerusakan ekosistem alam yang dilakukan oleh para pengusaha dan pemerintah.

Selain beberapa teks sastra tersebut, ada juga salah satu teks sastra yang memberikan gambaran tentang kerusakan ekosistem yang relevan dengan kondisi dunia modern. Teks sastra tersebut adalah cerpen Ikan karya Danang Febriansyah. Setelah membaca secara sepintas, dalam cerpen Ikan termuat adanya representasi 
tentang kerusakan ekosistem yang disebabkan oleh sikap (etika) manusia yang amoral. Salah satunya dalam bentuk pencemaran lingkungan yang disebabkan oleh limbah, baik limbah rumah tangga maupun industri. Pembuangan limbah rumah tangga dan pabrik direpresentasikan oleh Danang Febriansyah melalui salah satu karyanya tersebut. Sikap manusia yang tidak etis (amoral) digambarkan melalui alur teks cerpen. Selain itu, tokoh dalam teks cerpen juga digambarkan menunjukkan sikap yang amoral, terutama dengan menggunakan peralatan modern untuk memperoleh hasil ikan yang banyak dalam tempo singkat. Berbagai kondisi yang terefleksi dalam cerpen Ikan karya Danang Febriansyah merupakan sebuah wadah (media) bagi penulis untuk menyuarakan sekaligus memberikan pembelajaran kepada manusia agar lebih bersikap arif dalam memanfaatkan alam dengan berbagai jenis kekayaannya. Kajian tentang ekologi sastra, terutama krisis ekologi dalam teks sastra, penting dilakukan dengan tujuan agar memberikan kesadaran utuh kepada manusia tentang posisinya di tengah ekosistem alam.

Berdasarkan alasan dan latar belakang tersebut, penelitian ini bertujuan untuk mengidentifikasi bentuk krisis ekologi yang termuat dalam cerpen Ikan karya Danang Febriansyah dengan menggunakan perspektif ekokritik. Karya sastra bernuansa ekologis dan perspektif ekokritik perlu dikaji dan dipublikasikan kepada semua elemen masyarakat, baik akademisi maupun pembaca pada umumnya. Hal itu disebabkan karena dua buah konsep (terminologi) tersebut memberikan nilai moral kepada pembaca tentang sistematika pemanfaatan alam dengan berbagai jenis kekayaannya. Selain itu, penelitian dalam artikel ini juga bertujuan memberikan pemahaman kepada pembaca bahwa etika yang amoral (tidak etis) dapat memberikan dampak negatif terhadap eksistensi manusia dan makhuk hidup lainnya. Kajian tentang ekosistem alam dalam teks sastra perlu dikaji dengan tujuan untuk memberikan kesadaran penuh kepada masyarakat agar bersikap arif (bijaksana) terhadap berbagai bentuk kekayaan alam.

Selain penelitian dalam artikel ini, ada juga beberapa penelitian yang menggunakan perspektif ekokritik untuk menganalisis sebuah teks sastra. Beberapa penelitian tersebut yaitu pertama, penelitian yang dilakukan oleh Hannes Bergthaller, Rob Emmett, Adeline Johns-Putra, Agnes Kneitz, Susanna Lidström, Shane McCorristine, Isabel Pèrez Ramos, Dana Phillips, Kate Rigby, dan Libby Robin pada tahun 2014 dengan judul "Mapping Common Ground: Ecocriticism, Environmental History, and the Environmental Humanities". Salah satu tujuan penelitian yang dilakukan oleh Bergthaller, et al., tersebut yaitu untuk mengidentifikasi penyebab kerusakan ekosistem alam (krisis ekologi). Hasil penelitian menunjukkan bahwa penyebab krisis ekologi yang menyelimuti lingkungan hidup disebabkan oleh pandangan manusia yang antoposentris. Lambatnya pengetahuan dan pembelajaran yang dikhususkan kepada orang-orang yang memiliki pandangan tersebut menjadi penyebab tindakan memarginalkan ekologi.

Kedua, penelitian yang dilakukan oleh Maimunah pada tahun 2014 dengan judul "Perlawanan Alam Terhadap Kolonialisme dalam Cerpen Pohon Jejawi Karya Budi Darma”. Penelitian yang dilakukan oleh Maimunah bertujuan untuk mengidentifikasi bentuk representasi dari colonial ecocritism serta ideologi teks yang terkandung dalam cerpen Pohon Jejawi. Hasil penelitian menunjukkan 
bahwa dengan menggunakan perspektif green studies, cerpen Pohon Jejawi memberikan representasi tentang maskulinitas kolonial yang diwakili oleh tokoh utama dalam teks cerpen. Selain itu, cerpen Pohon Jejawi juga memberikan gambaran tentang perlawanan masyarakat dan pohon jejawi terhadap regulasi kapitalisme kolonial.

Ketiga, penelitian yang dilakukan oleh Randa Anggarista dan Nurhadi pada tahun 2018 dengan judul "Representasion of Benuaq Ethnic's Environemental Wisdom in the Novel of Api Awan Asap by Korrie Layun Rampan". Penelitian yang dilakukan oleh Anggarista dan Nurhadi tersebut bertujuan untuk mengidentifikasi bentuk kearifan lingkungan masyarakat Dayak Benuaq Kalimantan yang termuat dalam novel Api Awan Asap karya Korrie Layun Rampan. Hasil penelitian menunjukkan bahwa dalam novel Api Awan Asap termuat kearifan lingkungan masyarakat Dayak Benuaq dalam bentuk solidaritas terhadap alam, hidup sederhana dan selaras dengan alam, tanggung jawab terhadap alam, hormat terhadap alam, dan tidak merugikan alam.

Keempat, penelitian yang dilakukan oleh Randa Anggarista pada tahun 2020 dengan judul "Kritik Ekologi dalam Kumpulan Cerpen Cemara Karya Hamsad Rangkuti". Penelitian tersebut bertujuan untuk mengidentifikasi bentuk kritik ekologi dalam kumpulan cerpen Cemara karya Hamsad Rangkuti. Hasil penelitian menunjukkan bahwa dalam kumpulan cerpen Cemara karya Hamsad Rangkuti ditemukan adanya bentuk kritik yang berusaha disampaikan oleh pengarang, terutama kritik ekologi terhadap aktivitas penebangan pohon (illegal logging), perburuan margasatwa, serta pertambangan. Berdasarkan beberapa penelitian yang telah disebutkan di atas, belum ada penelitian yang menggunakan cerpen Ikan karya Danang Febriansyah sebagai objek penelitian. Selain itu, fokus penelitian dalam artikel ini juga berbeda dengan beberapa penelitian yang relevan dengan penelitian dalam artikel ini.

Karya sastra ekologis dan kajian ekokritik (ecocriticism) menjadi salah satu solusi untuk memberikan kesadaran utuh kepada manusia agar memiliki sikap yang bijaksana dalam memanfaatkan berbagai jenis kekayaan alam. Berdasarkan perspektif dalam ranah kritik sastra, ekokritik merupakan sebuah kajian yang berusaha mengkaji bagaimana alam dengan berbagai persoalan yang ada di dalamnya, khususnya relasi antara teks sastra dengan alam. Kerusakan ekologis dan munculnya berbagai bentuk krisis ekologi merupakan salah satu latar belakang lahirnya ekokritik. Sebelum lahirnya ekokritik, Garrard (2004:4) mengatakan bahwa pada awalnya, kajian yang bernuansa ekologi ditemukan dalam berbagai artikel yang termuat dalam The Association for the Study of Literature and Environment (ASLE) yaitu kajian yang fokus untuk menanggulangi krisis ekologi. Asosiai tersebut memiliki anggota dari berbagai negara, seperti United Kingdom, Jepang, Korea, hingga Australia. Namun seiring berkembangnya zaman, lahirlah sebuah terminologi dalam kritik sastra yang disebut sebagai ekokritik. Ekokritik menjadi kajian kontemporer yang fokus pada penelitian tentang relasi karya sastra dan ekosistem alam. Para sastrawan seringkali menggunakan diksi alam sebagai bagian penting untuk membangun teks sastra yang dihasilkannya. 
Ekokritik juga sama dengan aliran lainnya, terutama feminisme. Jika feminisme didasarkan pada perspektif sastra yang memberikan representasi tentang budaya patriarki dan gender dalam teks sastra, maka ekokritik lahir karena adanya tuntutan kondisi alam (lingkungan hidup). Adapun Bergthaller, et al (2014:269) mengatakan bahwa ekokritik muncul di Amerika Serikat pada tahun 1990. Para peneliti Amerika mengembangkan teori ekokritik dari feminis yang mengkaji dari ketidakadilan pada ranah gender, sehingga ekokritik berkembang menjadi sebuah kajian dalam ranah perkuliahan.

Setelah artikel yang bernuansa ekologis lahir dari para kalangan akademisi, maka muncul teori yang relevan dengan kondisi alam (lingkungan hidup). Berdasarkan konsep sederhananya, ekokritik menitikberatkan pada kajian sastra yang bernuansa ekologis, baik teks sastra yang memberikan representasi tentang perilaku tokoh dalam teks sastra, maupun kondisi alam yang termuat dalam teks sastra. Melalui buku yang berjudul The Future of Enviromental Criticism: Environemntal Crisis anda Literary Imagination Buell (2005:1) mengatakan bahwa ekokritik merupakan sebuah teori yang mengkaji relasi antara lingkungan hidup dan karya sastra. Degradasi ekologi dan sikap manusia yang amoral menjadi salah satu landasan dasar lahirnya kajian ekokritik. Komposisi diksi ekosistem alam yang digunakan para sastrawan dalam teks sastra yang dihasilkannya menjadi salah satu manifestasi perjuangan para sastrawan untuk memberikan kesadaran utuh kepada masyarakat tentang sistematika pemanfaatan alam (lingkungan hidup). Perubahan paradigma manusia, memberikan dampak negatif bagi perkembangan dunia dan manusianya. Salah satu dampaknya dapat ditemukan dengan munculnya berbagai bentuk krisis ekologi pada era modernisasi. Oleh karena itu, Taylor (2015:877-878) mengatakan bahwa ekokritik tidak hanya sebagai sebuah paradigma dalam ilmu sains, namun juga sebagai cara untuk memahami sejarah serta dampak dari krisis ekologi bagi masa depan. Lebih lanjut Piliang (1998:29) menyebutkan bahwa modernisasi dan indutrialisasi telah membawa dampak dengan musnahnya berbagai satwa atau terumbu karang yang diganti dengan mobil, televisi, dan berbagai peralatan modern lainnya. Bunyi siamang yang dulunya menyatu dengan napas kehidupan masyarakat pedesaan, diganti oleh suara mesin penebang kayu.

Oleh karena itu, untuk menanggulangi hal tersebut, para akademisi dan sastrawan berusaha menjadi pionir untuk memberikan kesadaran kepada manusia agar bersikap bijaksana dalam memanfaatkan alam. Melalui para akademisi lahir kajian yang bernuansa ekologis, misalnya literatur yang berjudul The Comedy of Survival: Studies in Literary Ecology yang ditulis oleh Joseph W. Meeker. Melalui buku tersebut, Meeker (1972) menjelaskan bahwa ekologi sastra relevan dengan konsep yang berusaha menganalisis atau memberikan analisis terhadap relasi antara kritik sastra dan ekologi (via Glotfelty, 1996:xix). Selain itu, dalam buku yang berjudul Practical Ecocriticism: Literature, Biology, and the Environment, Love (2003:37) menjelaskan bahwa kajian ekokritik merupakan sebuah terminologi yang dicetuskan oleh kaum akademisi, khususnya yang berprofesi dalam bidang sastra Inggris. Ekokritik membahas atau mengkaji kondisi lingkungan yang termuat dalam karya sastra. Hal itu disebabkan karena setiap karya yang lahir dari tangan seorang sastrawan tentu saja bukan dengan 
kekosongan perspektif. Para sastrawan biasanya membuat sebuah teks sastra dengan tujuan agar mampu memberikan informasi sekaligus sebagai media pembelajaran bagi manusia. Representasi alam yang terefleksi dalam sebuah teks sastra bisa saja menjadi sebuah wahana bagi pengarang (sastrawan) untuk menumbuhkembangkan kesensitifan manusia terhadap ekologi (lingkungan hidup).

Hadirnya ekokritik dalam ranah kritik sastra tentu saja bukan dengan tanpa maksud. Sama seperti aliran lain dalam kritik sastra, misalnya feminisme mengkaji teks sastra dari sudut pandang keperempuanan dan marxis mengkaji teks sastra dari sudut pandang ekonomi (kapitalisme), maka ekokritik juga mengkaji sebuah teks sastra dengan memperhatikan konteks alam (lingkungan hidup). Ekokritik merupakan kajian yang mengidentifikasi relasi antara teks sastra dengan lingkungan (Glotfelty, 1996:xix). Pandangan yang sama juga dikemukakan oleh Richard Kerridge's (1998:5) bahwa ekokritik bertujuan untuk mengidentifikasi teks sastra yang bedasarkan pada topik tentang lingkungan hidup serta untuk menemukan solusi dalam setiap perdebatan (diskusi) tentang polemik yang ada di tengah ekosistem. Perkembangan zaman dan sifat manusia yang konsumtif menjadi salah satu kondisi (fenomena) yang harus diperhatikan oleh seluruh elemen masyarakat. Hal yang sama juga disampaikan oleh Goldwyn (2015:67) bahwa ekokritik berusaha menganalisis representasi perubahan lingkungan hidup, perubahan iklim, dan krisis ekologi yang termuat dalam teks sastra.

Kajian ekokritik yang telah berkembang di negara-negara Eropa, merambah ke tengah kalangan para akademisi di Indonesia. Beberapa akademisi yang memberikan fokus pada penelitian tentang kajian ekokritik di Indonesia yaitu Wiyatmi. Melalui salah satu bukunya yang berjudul Kritik Sastra Indonesia: Feminisme, Ekokritisisme, dan New Historisme, Wiyatmi (2015:9) menjelaskan bahwa kajian ekokritik merupakan sebuah perspektif yang memberikan perhatian terhadap hubungan timbal balik antara teks sastra dengan lingkungan. Ekokritik menjelaskan bagaimana alam dengan berbagai persoalaannya menjadi bagian yang tidak bisa dipisahkan dengan karya sastra.

Selain Wiyatmi, dalam buku yang berjudul Ekokritik Sastra:Konsep, Teori dan Terapan, Endraswara juga memberikan titik fokus pada kajian tentang menumbuhkembangkan kearifan lingkungan. Endraswara (2016:48) mengatakan bahwa ekokritik bertujuan untuk memberikan penilaian tentang bobot sebuah teks sastra dengan mempertimbangkan aspek ekologi. Kajian ini berusaha menafsirkan sebuah teks sastra dengan memperhatikan lingkungan. Alam (lingkungan hidup) seringkali menjadi pijakan bagi para sastrawan untuk menghasilkan sebuah teks sastra. Selain itu, alam (lingkungan hidup) bukan hanya sebatas sebagai latar, namun juga sebagai aspek yang membangun teks sastra. Ekokritik tidak hanya merupakan sebuah paradigma, namun juga sebagai salah satu bentuk komitmen sekaligus wadah untuk melakukan rehabilitasi terhadap kasus marginalisasi lingkungan hidup (Schickling, 2011:80).

Berdasarkan beberapa definisi yang disampaikan oleh kalangan akademisi tersebut dapat disimpulkan bahwa kajian ekokritik merupakan salah satu wadah dan manifestasi untuk memperjuangkan eksistensi alam. Sama seperti kajian yang lain, misalnya feminisme yang menitikberatkan pada teks sastra bernuansa gender, 
new historisme yang memiliki fokus pada kajian sastra bernuansa sejarah, serta postkolonial yang menitikberatkan pada kajian tentang teks sastra bernuansa kolonial, maka ekokritik menitikberatkan pada teks sastra bernuansa ekologis. Ekokritik berusaha mengkaji relasi antara teks sastra dengan lingkungan hidup, bagaimana sikap para tokoh terhadap alam dalam teks sastra, serta bagaimana alam direpresentasikan dalam teks sastra.

\section{METODE}

Penelitian ini merupakan penelitian kualitatif dengan menggunakan perspektif ekokritik. Data dalam penelitian ini teks yang mengacu pada rumusan masalah tentang bentuk krisis ekologi dalam cerpen Ikan, sedangkan sumber data yang digunakan yaitu cerpen Ikan karya Danang Febriansyah yang termuat dalam antologi Temukan Warna Hijau. Instrumen dalam penelitian ini yaitu penulis yang berorientasi pada penelitian teks cerpen Ikan karya Danang Febriasnsyah. Uji validitas dalam penelitian ini menggunakan validitas semantis yang berorientasi pada kedalaman proses interpretasi. Validitas semantis bertujuan untuk mengidentifikasi teks yang merepresentasikan tentang krisis ekologi dalam teks cerpen. Teknik pengumpulan data dalam penelitian ini dilakukan dengan membaca dan mencatat berbagai teks yang memberikan indikasi tentang adanya representasi krisis ekologi. Adapun teknik analisis data yang digunakan yaitu klasifikasi, interpretasi, dan penarikan simpulan.

\section{PEMBAHASAN}

Berdasarkan hasil identifikasi terhadap sumber data, dalam cerpen Ikan ditemukan adanya bentuk krisis ekologi yang terefleksi melalui teks, baik kata, kalimat, maupun paragraf dalam cerpen tersebut. Berikut ini penulis paparkan dalam bentuk tabel tentang bentuk krisis ekologi dalam cerpen Ikan karya Danang Febriansyah. Krisis ekologi dalam teks cerpen ditemukan melalui alur bahkan dialog antar tokoh. Tabel berikut berisi deskripsi singkat tentang bentuk krisis ekologi yang termuat dalam cerpen Ikan karya Danang Febriansyah.

\begin{tabular}{ll}
\hline \multicolumn{1}{c}{ Bentuk Krisis Ekologi } & \multicolumn{1}{c}{ Deskripsi } \\
\hline Pencemaran ekosistem biotis & $\begin{array}{l}\text { Kerusakan ekosistem sungai yang } \\
\text { disebabkan oleh limbah pabrik dan rumah } \\
\text { tangga. }\end{array}$ \\
\hline $\begin{array}{l}\text { Punahnya makhluk hidup dalam } \\
\text { ekosistem sungai }\end{array}$ & $\begin{array}{l}\text { Tokoh dalam teks cerpen melakukan } \\
\text { pengerusakan terhadap ekosistem alam } \\
\text { dengan menggunakan racun dan peralatan } \\
\text { modern untuk memperoleh hasil ikan. }\end{array}$
\end{tabular}

Setelah melakukan identifikasi dengan membaca secara keseluruhan teks cerpen Ikan karya Danang Febriansyah, ditemukan adanya bentuk representasi krisis ekologi yang berusaha disampaikan oleh pengarang. Berikut ini penulis paparkan representasi bentuk krisis ekologi dalam cerpen Ikan karya Danang Febriansyah. 


\section{Pencemaran Ekosistem Biotis}

Setelah melakukan identifikasi terhadap objek penelitian, dalam teks cerpen Ikan karya Danang Febriansyah, ditemukan adanya representasi tentang kerusakan ekosistem sungai. Melalui teks cerpen tersebut, Danang berusaha memberikan gambaran bahwa kerusakan ekosistem alam, khususnya sungai, merupakan bagian yang tidak bisa terpisahkan dari perubahan sikap manusia terhadap ekosistem alam. Hal itu dibuktikan melalui potongan teks data berikut ini.

Sungai yang menjorok ke area sawah itu tak akan dibendung jika tak ada kejadian yang kini masih terselimuti misteri (Febriansyah, 2014:136-137).

Ikan-ikan yang mendiaminya, yang tiap hari selalu berlompatan ke atas air atau paling tidak berkejaran dengan ikan yang lain, kini seakan lenyap tak berdaya. Ekosistem sungai itu tampak kosong. Sungai yang keceriaannya mendamaikan hati, sungai yang menyimpan banyak misteri, sungai yang mengelola kesabaran itu, kini tampak menangis. Gemercik air yang sebetulnya tampak seperti orkes alam terdengar seperti tangisan yang menyayat hati (Febriansyah, 2014:136).

Cerpen Ikan memberikan gambaran tentang problematika yang terjadi di wilayah Indonesia. Kerusakan ekosistem sungai akibat pandangan manusia yang antroposentris menjadi salah satu penyebab perubahan lingkungan. Berdasarkan potongan teks data pertama di atas terlihat bahwa kondisi ekosistem biotis atau sungai mengalami perubahan karena sikap manusia yang amoral. Ekosistem sungai yang memberikan manfaat terhadap keberlangsungan eksistensi manusia tidak sejalan dengan etika manusia dalam memeliharanya. Sungai tidak lagi menjadi sumber kehidupan manusia, namun justru menjadi sebuah wadah untuk membuang berbagai jenis limbah. Hal itu tentu saja bersifat kontradiktif dengan salah satu prinsip etika lingkungan hidup, salah satunya sikap solidaritas kosmis. Keraf (2010:172) menjelaskan bahwa sikap solidaritas kosmis diwujudkan dengan menerapkan regulasi yang memberikan dukungan terhadap keberlangsungan eksistensi lingkungan hidup, terutama agar manusia tidak merusak dan mencemari lingkungan hidup. Salah satu tujuan prinsip solidaritas kosmis adalah sebagai pengendali moral sekaligus alat kontrol terhadap perilaku manusia.

Bahkan dalam teks data kedua di atas juga semakin menguatkan adanya representasi krisis ekologi dalam bentuk kerusakan ekosistem biotis. Berdasarkan teks kedua di atas terlihat bahwa kondisi ekosistem sungai yang pada awalnya bersih, bahkan menjadi sumber kehidupan bagi masyarakat, telah menjadi sebuah ekosistem yang tidak terawat. Sikap masyarakat yang amoral atau tidak mengedepankan rasa hormat terhadap alam dengan menjaga dan merawatnya, merupakan salah satu penyebab kerusakan ekosistem sungai. Melalui teks cerpen tersebut, Danang Febriansyah berusaha menyuarakan sebuah kondisi yang begitu mengkhawatirkan. Selain itu, kondisi yang digambarkan oleh Danang Febriansyah dalam teks cerpen tersebut merupakan manifestasi atau sarana kritik penulis dengan adanya sikap amoral manusia dan munculnya degradasi ekologi di tengah ekosistem. Alur cerita teks cerpen yang memberikan representasi tentang krisis 
dan kritik ekologi cukup relevan dengan kondisi dunia modern. Penggunaan berbagai jenis peralatan modern untuk memberikan kemudahan bagi manusia, tentu saja tidak selamanya memberikan dampak positif. Bahkan berdasarkan pantauan Kementerian Lingkungan Hidup Republik Indonesia (LH RI) tahun 2014, menjelaskan bahwa sebanyak 75\% sungai di wilayah Indonesia tercemar akibat pembuangan limbah rumah tangga. Saluran pembuangan air serta kepemilikan jamban pada masyarakat yang tidak memadai mengakibatkan kualitas air sungai menurun. Berbagai bentuk penyebab kerusakan ekosistem sungai yang termuat dalam laporan Kementerian Lingkungan Hidup Republik Indonesia tersebut, terepresentasi dalam teks sastra yang dihasilkan oleh Danang Febriansyah.

Selain potongan teks data di atas, melalui salah satu potongan teks data berikut ini, pengarang berusaha memberikan penekanan pada teks naratif yang dihasilkannya tentang kerusakan ekosistem serta dampaknya bagi makhluk hidup di dalamnya.

Kail yang sejak tadi dipasang belum juga menampakkan hasil. Cacing sawah yang terkait di mata kail makin tersiksa. Nyawa tak juga lepas dari tubuh berlendirnya. Ikan-ikan di sungai sepertinya enggan untuk makan siang atau mungkin mereka telah dibantai habis tanpa sisa (Febriansyah, 2014:137)

Ikan-ikan memang jarang keluar kalau hari masih pagi. Tapi, mungkin juga ikan punya indra yang bisa mencium bau tak sedap yang mengalir bersama riak air sungai. Ya, polusi air yang akan meracuni hidup mereka (Febriansyah, 2014:137)

Kerusakan ekosistem biotis, seperti yang digambarkan Danang Febriansyah juga termuat dalam alur cerita selanjutnya. Kondisi ekosistem sungai yang telah kotor, terutama dengan munculnya berbagai jenis limbah, baik limbah pabrik maupun rumah tangga, ternyata berdampak negatif terhadap eksistensi makhluk hidup di dalamnya. Berdasarkan teks data di atas terlihat bahwa pembuangan limbah ke dalam ekosistem sungai ternyata menjadi salah satu penyebab munculnya degradasi ekologi. Kondisi air sungai yang tidak lagi terjaga, membuat makhluk hidup penghuni ekosistem menjadi terancam. Kondisi tersebut diperparah dengan sikap antroposentris manusia yang tidak menjunjung tinggi prinsip etika lingkungan hidup yaitu hidup sederhana dan selaras dengan alam. Keraf (2010:175) menjelaskan bahwa sikap hidup sederhana dan selaras dengan alam diwujudkan dengan cara memanfaatkan alam seperlunya dan sesuai dengan tuntutan kebutuhan. Berdasarkan teks data di atas terlihat bahwa alur cerita memberikan representasi tentang sikap manusia yang tidak sejalan dengan prinsip hidup sederhana dan selaras dengan alam tersebut.

Bahkan pada teks berikutnya juga terlihat bahwa limbah pabrik dan rumah tangga, menyebabkan ekosistem sungai tercemar dan menimbulkan polusi. Kondisi air sungai yang tidak bersih, menyebabkan berbagai ikan yang ada di dalamnya lenyap dan mati dengan tiba-tiba. Kerusakan ekosistem sungai seperti 
yang digambarkan oleh Danang Febriansyah dalam teks cerpen tersebut juga begitu representatif jika dikomparasikan dengan dunia faktual saat ini. Kerusakan ekosistem sebenarnya tidak hanya menimbulkan dampak negatif bagi makhluk hidup seperti flora dan fauna, namun juga bagi manusia secara keseluruhan. Pembuangan limbah, baik limbah rumah tangga maupun pabrik, menyebabkan aliran sungai terhambat, sehingga menimbulkan bencana dalam bentuk banjir. Sifat manusia sebagai makhluk ekologis tentu saja seharusnya menjadi salah satu landasan utama dalam menerapkan berbagai bentuk regulasi yang berkaitan dengan pemanfaatan ekosistem alam dengan berbagai jenis kekayaannya. Hal itu disebabkan karena apabila ekosistem alam dengan berbagai jenis kekayaannya mengalami kepunahan, maka eksistensi manusia juga ikut terancam.

Melalui teks cerpen tersebut, Danang Febriansyah berusaha memberikan gambaran sekaligus pesan kepada pembaca dan masyarakat pada umumnya bahwa sikap amoral yang ditunjukkan oleh manusia tentu saja akan memberikan dampak negatif terhadap eksistensi ekosistem alam, terutama dengan munculnya berbagai jenis degradasi ekologi. Alam dengan berbagai jenis kekayaannya merupakan aspek penting bagi kehidupan manusia dan generasinya. Oleh karena itu, menunjukkan sikap solidaritas serta mengedepankan sikap hidup sederhana dan selaras dengan alam merupakan manifestasi rasa syukur manusia kepada Tuhan sekaligus wujud terima kasih manusia kepada alam.

\section{Punahnya Makhluk Hidup dalam Ekosistem Sungai}

Selain kerusakan ekosistem biotis (sungai), dalam cerpen Ikan karya Danang Febriansyah juga ditemukan adanya bentuk krisis ekologi yang berusaha disampaikan oleh pengarang melalui teks naratif yang dihasilkannya. Setelah melakukan eksplorasi terhadap teks cerpen, ditemukan adanya bentuk representasi tentang degradasi ekologi yaitu punahnya makhluk hidup dalam ekosistem biotis (sungai). Hal itu dibuktikan melalui potongan teks data berikut ini.

"Ayo, cepat gosok. Kita akan memakan sesuatu yang bergizi hari ini", seorang remaja bercelana pendek memberi perintah pada temannya yang sedang jongkok di bebatuan.

"Iya, ini baru digosok," jawab temannya sambil mencelupkan kedua tangan yang menggosok-gosokkan sebuah benda putih sebesar kepala ayam hingga benda itu larut dalam air sungai (Febriansyah, 2014:138).

Tak lama kemudian, beberapa anak ikan mengelepar di permukaan air. Tak sampai lima menit, mereka lalu mati (Febriansyah, 2014:138).

Satu demi satu ikan-ikan menggelepar keracunan. Dengan mudah, dua remaja itu menangkpanya satu per satu. Tak peduli induk atau anak. Semua mati karena racun potasium yang harganya relatif murah.... (Febriansyah, 2014:139).

Perubahan sikap manusia tentu saja menjadi salah satu penyebab kerusakan ekosistem alam. Pandangan manusia yang antroposentris dan tidak sejalan dengan 
prinsip etika lingkungan hidup berdampak negatif terhadap eksistensi makhluk hidup lainnya. Berdasarkan teks data pertama di atas terlihat bahwa sikap manusia yang konsumtif sejalan dengan perilakunya dalam memanfaatkan kekayaan alam. Melalui potongan teks data tersebut, Danang Febriansyah berusaha memberikan gambaran bahwa para tokoh menggunakan peralatan modern untuk mendapatkan hasil ikan yang lebih maksimal. Pada dasarnya, manusia sebagai makhluk ekologis memiliki tanggung jawab moral untuk memberikan perhatian secara utuh terhadap kekayaan ekosistem alam. Sebagai makhluk ekologis yang tidak bisa memisahkan diri dari eksistensi alam, manusia harus mengedepankan etika hidup sederhana dan selaras dengan alam, tidak eksploratif dan konsumtif. Potongan teks data tersebut juga menjadi salah satu representasi tentang perilaku manusia modern dalam memanfaatkan alam. Para tokoh dalam teks cerpen digambarkan sebagai tokoh antagonis yang berusaha melakukan pengerusakan terhadap kekayaan ekosistem alam.

Gambaran tentang punahnya makhluk hidup dalam ekosistem biotis (sungai) akibat perilaku amoral manusia juga digambarkan pada potongan teks kedua di atas. Melalui potongan teks data kedua di atas terlihat bahwa kerusakan ekosistem sungai membuat eksistensi makhluk hidup yanga ada di dalamnya menjadi terancam. Berdasarkan potongan teks data di atas, penulis berusaha memberikan gambaran bahwa sungai tidak lagi menjadi sebuah ekosistem yang hidup, namun justru menjadi sumber kepunahan makhluk hidup yang ada di dalamnya. Alur cerita teks cerpen menjelaskan tentang berbagai jenis makhluk hidup yang ada di sepanjang aliran sungai, mengalami kepunahan. Kondisi tersebut tentu saja merupakan representasi dari sikap manusia yang tidak menunjukkan etika dalam menggunakan berbagai bentuk kekayaan alam. Hal itu menjadi sebuah pekerjaan rumah bagi pemerintah untuk memberikan kesadaran kepada masyarakat bahwa sungai merupakan aspek fundamental yang menunjang eksistensi manusia di atas permukaan bumi.

Melalui bukunya yang berjudul Etika Lingkungan Hidup, Keraf (2010:171) menjelaskan bahwa pada dasarnya manusia sebagai makhluk ekologis memiliki beban dan tanggung jawab untuk menanamkan prinsip solidaritas terhadap alam. Sikap tersebut diwujudkan dengan cara menerapkan regulasi atau peraturan yang mendukung eksistensi alam (lingkungan hidup). Representasi yang disampaikan oleh Danang Febriansya dalam teks cerpen tersebut pada dasarnya menjadi sebuah pembelajaran bagi manusia agar bersikap arif terhadap alam dengan berbagai jenis kekayaannya.

Bahkan berdasarkan potongan teks data ketiga di atas terlihat jelas tentang representasi sikap manusia yang melanggar prinsip kasih sayang dan kepedulian terhadap alam. Sikap ini diwujudkan dengan melakukan pertimbangan terhadap perbuatan yang akan diterapkan (Keraf, 2010:172). Melalui potongan teks data ketiga di atas, Febriansyah berusaha menjelaskan bahwa sikap manusia yang eksploitatif yaitu dengan memanfaatkan alam secara berlebihan, terutama dengan tidak melakukan pertimbangan terhadap kebutuhan dan keberlanjutan eksistensi makhluk hidup lainnya, menjadi penyebab punahnya makluk hidup di dalam ekosistem. 
"Anaknya sudah mulai tampak, kita tunggu induknya."

"Kita tombak saja airnya, biar potasnya merata" (Febriansyah, 2014:138).

"Itu dia penebar terornya"

Dia lalu melompat dari batu satu ke batu lain dengan cekatan untuk mendekati dua remaja itu.

"Hei, apa yang kalian lakukan?!" Teriaknya.

Dua remaja itu terkejut bukan main karena melihat seseorang sedang mengejar mereka sambil mengacungkan pancing. Mereka lalu lari tunggang langgang. Satu remaja membawa hasil ikan yang diracunnya, ditenteng dengan tali rumput ilalang. Yang satu, lari tak peduli (Febriansyah, 2014:141).

Berbagai bentuk degradasi ekologi yang digambarkan oleh Danang Febriansyah melalui teks cerpen Ikan tersebut sejalan dengan sikap dan etika manusia dalam memanfaatkan alam. Sikap manusia yang eksploitatif dan konsumtif tentu saja memberikan dampak terhadap perubahan kondisi lingkungan hidup. Kerusakan ekosistem yang berdampak pada punahnya berbagai jenis makhluk hidup, ternyata bukan hanya disebabkan oleh limbah rumah tangga dan pabrik, namun juga disebabkan oleh paradigma manusia. Melalui teks di atas Danang Febriansya berusaha memberikan gambaran tentang penyebab punahnya berbagai jenis ikan yang ada di dalam ekosistem sungai. Sikap manusia yang eksploitatif, terutama penggunaan tombak untuk mendapatkan ikan dengan jumlah besar, ternyata menjadi pemicu lain bagi kerusakan dan punahnya makhluk hidup yang ada di dalam ekosistem sungai.

Selain itu, melalui potongan teks data di atas terlihat adanya representasi tentang perlawanan tokoh lainnya terhadap aktivitas yang dilakukan oleh dua remaja (tokoh antagonis) dalam teks cerpen. Punahnya berbagai jenis ikan dalam ekosistem biotis (sungai), mendapat perlawanan dari tokoh lainnya. Hal itu tentu saja sebagai salah satu manifestasi sekaligus implementasi dari prinsip tanggung jawab sesuai yang dijelaskan oleh Keraf (2010:169). Sikap tersebut diwujudkan dengan cara mengingatkan, melarang, dan menghukum siapa saja yang berusaha melakukan pengerusakan terhadap ekosistem alam. Alur cerita yang disampaikan Danang Febriansyah melalui teks cerpen tersebut sebagai salah satu alternatif bagi masyarakat untuk menerapkan kebijakan agar eksistensi alam dan makhluk hidup yang ada di dalamnya tidak mengalami ancaman. Sebagai makhluk ekologis, manusia memiliki tanggung jawab untuk memberikan peringatan dan menghukum semua pihak yang berusaha melakukan pengerusakan atau eksploitasi terhadap kekayaan alam.

Dua bentuk representasi tentang degradasi atau krisis ekologis dalam tesk cerpen tersebut sebagai salah satu manifestasi terhadap kondisi perilaku manusia terhadap ekosistem alam dengan berbagai jenis kekayaannya. Teks naratif tersebut juga menjadi sarana kritik bagi penulis terhadap manusia yang konsumtif dan tidak mengedepankan asas serta prinsip etika lingkungan hidup. Kondisi degradasi ekologi dalam bentuk kerusakan ekosistem biotis dan punahnya makhluk hidup 
(ikan) dalam sebuah ekosistem menjadi representasi tentang kondisi dunia modern, terutama dengan menjamurnya penggunaan peralatan modern yang dianggap memberikan kemudahan bagia kehidupan manusia. Namun, berbagai bentuk peralatan modern tersebut tentu saja menjadi salah satu penyebab munculnya perubahan kondisi lingkungan hidup sekaligus paradigma manusia sebagai makhluk ekologis dalam memandang posisinya di tengah ekosistem alam.

\section{PENUTUP}

Berdasarkan hasil interpretasi terhadap teks data, dalam cerpen Ikan karya Danang Febriansyah ditemukan adanya bentuk krisis ekologi yang bersusaha disampaikan oleh pengarang, seperti kerusakan ekosistem biotis (biotis) serta punahnya makhluk hidup dalam sebuah ekosistem. Dua bentuk degradasi atau krisis ekologi dalam teks cerpen tersebut memberikan representasi tentang dampak dari sikap manusia yang amoral, konsumtif, serta eksploitatif. Salah satu tujuan teks sastra yang bernuansa ekologi, seperti dalam teks cerpen Ikan karya Danang Febriansyah tersebut merupakan salah satu manifestasi atau pengendali moral manusia agar bersikap bijaksana terhadap eksistensi alam (lingkungan hidup).

\section{DAFTAR PUSTAKA}

Ajidarma, Seno Gumira, dkk. (2014). Dodolitdodolitdodolibret. Jakarta: Kompas. Anggarista, Randa dan Nurhadi. (2018). "Representasion of Benuaq Ethnic's Environemental Wisdom in the Novel of Api Awan Asap by Korrie Layun Rampan". International Journal of Language and Literature, 6 (1), 38-45.

Anggarista, Randa. (2020). Kritik Ekologi dalam Kumpulan Cerpen Cemara Karya Hamsad Rangkuti. JURNALISTRENDI: Jurnal Linguistik, Sastra, dan Pendidikan, 6 (1), 56-65.

Bergthaller, Hannes, et al. (2014). "Mapping Common Ground: Ecocriticism, Environmental History, and the Environmental Humanities". Environmental Humanities, 5, 261-276.

Buell, Lawrence. (2005). The Future of Enviromental Criticism: Environemntal Crisis anda Literary Imagination. USA: Blackwell Publishing.

Endraswara, Suwardi. (2016). Ekokritik Sastra: Konsep, Teori, dan Terapan. Yogyakarta: Morfalingua.

Febriansyah, Danang. (2014). Ikan. Jakarta: PT Elex Media Komputindo.

Garrard, Greg. (2004). Ecocriticism: The New Critical Idiom. London and New York: Routledge.

Glotfelty, C and Harold F. (1996). The Ecocriticism Reader: Landmarks in Literary Ecology. London: University of Georgia Press.

Goldwyn, Adam J. (2015). "Toward a Byzantine Ecocriticism: Witches and Nature Control in the Medieval Greek Romance". Byzantine and Modern Greek Studies, 39 (1), 66-84.

Keraf, A. S. (2010). Etika Lingkungan Hidup. Jakarta: PT Kompas Media Nusantara.

Love, Glen A. (2003). Practical Ecocriticism: Literature, Biology, and The Environment. USA: University of Virginia Press. 
Maimunah. (2014). "Perlawanan Alam terhadap Kolonialisme dalam Cerpen Pohon Jejawi Karya Budi Darma”. Jurnal Litera, 13 (2), 326-337.

Peraturan Menteri RI, Direktorat Jenderal Pengairan. (2014). Keputusan Direktur Jenderal Pengairan Nomor 1451/KPTS/A/2014/ Tentang Standar Perencanaan Drainase.

Piliang, Y. A. (1998). Sebuah Dunia Yang Dilipat. Bandung: Mizan.

Richard, K. (1998). Small Rooms and The Ecosystem: Environmentalism and De Lillo's White Noise, in Kerridge, R., and Sammells, N. (eds). London: Zed Books.

Santoso, Tosca. (2012). Sarongge. Jakarta: Dian Rakyat.

Schickling, Jared. (2011). "Ecocriticism, Ecopoetics, Legibility: Among Other Things, the Objectively Signified". Literary Imagination, 13 (1), 80-88.

Taylor, Jesse Oak. (2015). "There is Victorian Ecocriticism". Victorian Literature and Culture, 43, 877-894.

Tohari, Ahmad. (2011). Ronggeng Dukuh Paruk. Jakarta: Gramedia Pustaka Utama.

Wiyatmi. (2015). Kritik Sastra Indonesia: Feminisme, Ekokritisisme, dan New Historisme. Yogyakarta: Interlude. 